\title{
Manajemen pembelajaran pada masa pandemi covid-19 berbasis blended learning
}

\author{
Fitrah Maulana Adri ${ }^{\left.1^{*}\right)}$, Muhammad Giatman ${ }^{2}$, Ernawati $^{3}$ \\ ${ }^{1}$ Universitas Negeri Padang
}

\begin{tabular}{l} 
Article Info \\
\hline Article history: \\
Received Apr $25^{\text {th }}, 2021$ \\
Revised May $24^{\text {th }}, 2021$ \\
Accepted Jun $24^{\text {th }}, 2021$ \\
\hline
\end{tabular}

\section{Keyword:}

Manajemen pembelajaran Covid-19

Blended learning

\begin{abstract}
Pada masa Pandemi covid 19, seluruh aktifitas lembaga kependidikan madrasah/ sekolah harus melaksanakan proses pembelajaran dalam jaringan (daring). Salah satu inovasi pembelajaran yang bisa dilakukan oleh madrasah/ sekolah yaitu dengan menerapkan pembelajaran berbasis Blended Learning. Penelitian ini bertujuan untuk mengetahui Manajemen, perencanaan pembelajaran, dan evaluasi pembelajaran berbasis Blended Learning di MTsN 3 Pasaman. Jumlah responden pada penelitian ini terdiri dari 10 guru bidang studi dan 30. Penelitian menggunakan teknik analisis data kualitatif dengan metode deskriptif. Hasil penelitian menunjukkan bahwa pada tahap perencanaan, sekolah merumuskan kurikulum khusus yang disesuaikan dengan model pembelajaran Blended Learning di masa Pandemi Covid-19 dan didukung sarana dan prasana belajar yang memadai. Pada tahap implementasi, ada perbedaan sedikit antara teori dan data riil dari segi waktu pembelajaran luring dan daring. Sekolah MTsN 3 Pasaman menerapkan sistem shift, seminggu pembelajaran luring dan di minggu yang lain pembelajaran daring, sedangkan, pembelajaran online/daring disesuaikan dengan kebutuhan masing-masing guru. Pada tahap evaluasi sekolah melaksanakan evaluasi secara tatap muka/luring dan online/daring berbasis website.
\end{abstract}

(C) 2021 The Authors. Published by IICET.

This is an open access article under the CC BY-NC-SA license (https://creativecommons.org/licenses/by-nc-sa/4.0

\section{Corresponding Author:}

Fitrah Maulana Adri,

Universitas Negeri Padang

Email: fitrahmaulana0397@gmail.com

\section{Pendahuluan}

Pembelajaran di sekolah/madrasah pada saat ini dilaksanakan dengan metode berpusat pada mahasiswa (student centered learning). Dalam pembelajaran yang berpusat pada siswa, siswa sebagai peserta didik dituntut untuk mampu memotivasi diri sendiri dalam belajar sehingga daapat menumbuhkan budaya belajar mandiri. Belajar mandiri pada siswa dapat didorong oleh guru melalui banyak cara, diantaranya melaului diskusi, penugasan penulisan makalah, pembuatan proyek, studi kasus, atau perancangan percobaan. Pada Era peradaban dalam pandemi Covid-19 atau yang sering disebut dengan "New Normal", memaksa pendidikan harus meninggalkan konsep pembelajaran lama yang masih mengandalkan 100\% tatap muka antara pendidik dan peserta didik berpindah ke penggunaan basis teknologi informasi dan komunikasi (TIK). Melalui Kementerian Pendidikan dan Kebudayaan di sebagian kota dan propinsi, pemerintah telah melarang sekolah/madrasah melaksanakan pembelajaran tatap muka (konvensional) dan memerintahkan untuk menyelenggarakan pembelajaran dilakukan secara daring yang disahkan melalui Surat Edaran Kemendikbud Dikti No. 1 tahun 2020.(Rahmati et al., 2020) 
Dengan kebijakan yang dikeluarkan oleh pemerintah maka sekolah dituntut untuk melakukan inovasi dalam seluruh aspek proses pembelajaran yang ada disekolah tersebut. Dalam hal ini manajemen pembelajaran merupakan salah satu acuan yang penting dalam melaksanakan proses belajar mengajar demi menunjang keberhasilah belajar pada masa pandemic Covid-19 ini. . Proses pembelajaran akan berlangsung baik, menarik dan dapat meningkatkan motivasi minat belajar peserta didik karena ketepatan mmanajemen pembelajaran yang diterapkan. Manajemen merupakan proses untuk mencapai tujuan organisasi oleh seseorang atau sekelompok orang melalui penggunaan berbagai fungsi yakni perencanaan, pengorganisasian, kepemimpinan, serta pengendalian. Pembelajaran merupakan kegiatan dimana terjadinya suatu interaksi antara peserta didik, dengan lingkungan belajarnya dengan tujuan perubahan tingkah laku yang bersifat konstruktif pada peserta didik. Berdasarkan hal tersebut maka dapat diartikan bahwa manajemen pembelajaran sebagai aktivitas atau kegiatan belajar dan mengajar melalui penerapan prinsip pembelajaran dengan mengacu kepada langkah-langkah pembelajaran meliputi perencanaan, pelaksanaan, serta evaluasi yang berguna untuk mengukur ketercapaian rencana serta tujuan dari pembelajaran yang ditetapkan.(Kurniawati, 2021)

Manajemen pembelajaran berbasis Blended Learning pada masa Pandemi Covid-19 pada lembaga pendidikan adalah salah satu komponen pendidikan yang sangat penting diperhatikan karena yang menjadi input, proses, dan output adalah peserta didik. Manajemen pembelajaran peserta didik yang baik dan bemutu berkontribusi pada adanya output pendidikan yang bermutu. Oleh sebab itu, manajemen pembelajaran berbasis Blended Learning pada masa Pandemi Covid-19 perlu dilaksanakan secara optimal agar mampu mendukung ketercapaian tujuan pendidikan, baik dalam tujuan kurikuler (mata pelajaran), tujuan institusional (lembaga/satuan pendidikan), maupun tujuan pendidikan nasional (Badrudin, 2014). Terdapat tiga komponen kunci utaman yang mempengaruhi keefektifan penerapan TIK dalam pengajaran dan pembelajaran, yaitu pedagogi, interaksi sosial dan teknologi. Akan tetapi, selain dari ketiga komponen yang dijabarkan tersebut maka kemampuan manajemen juga merupakan keterampilan yang penting diterapkan dalam rangka melaksanakan proses pembelajaran berbasis TIK. Dalam hal ini MTsN 3 Pasaman menerapkan system manajemen pembelajaran berbasis Blanded Learning.(Islamic \& Manajemen, 2020)

Secara etimologi istilah blended learning berasal dari dua suku kata yaitu blended dan learning. Blend yang berarti "gabungan atau campuran, berfungsi untuk meningkatkan kualitas agar bertambah baik", atau formula suatu penyelarasan kombinasi atau penyelarasan perpaduan. Sedangkan learning memiliki makna secara umum yaitu belajar, dengan demikian sepintas mengandung makna pembelajaran yang mengandung arti pencampuran, atau penggabungan yakni antara satu pola dengan pola yang lainnya. Jadi, blended learning adalah kombinasi pembelajaran tradisional dan lingkungan pembelajaran elektronik. Penerapan blended learning diharapkan siswa dapat memahami materi dengan lebih baik dan lebih aktif dalam mengikuti pembelajaran, sehingga dapat meningkatkan hasil belajar siswa, perlu dilaksanakan secara optimal agar mampu mendukung ketercapaian tujuan pendidikan, baik dalam tujuan kurikuler (mata pelajaran), tujuan institusional (lembaga/satuan).(Rahmati et al., 2020)

Di Provinsi Sumatera barat, salah satu kabupaten yang termasuk zona hijau adalah Kabupaten Pasaman. Berdasarkan Peraturan Bupati Kabupaten Pasaman, sejak awal Agustus lembaga Pendidikan di Kabupaten Pasaman diizinkan melaksanakan proses pembelajaran secara tatap muka (luring) dengan tetap memperhatikan protokol kesehatan. Di antara Madarasah yang menggunakan pembelajaran berbasis Blended Learning di Kabupaten Pasaman adalah MTsN 3 Pasaman. Madrasah Tsanawiyah tersebut merupakan lembaga pendidikan Islam yang bisa dijadikan contoh dalam pelaksanaan proses pembelajaran masa Pandemi Covid-19 di Kabupaten Pasaman. MTsN 3 Pasaman memiliki sarana berbasis TIK yang memadai sehingga mendukung peserta didik dalam melaksanakan proses pembejaran berbasis Blended Learning, contohnya seperti tersedianya laboratorium komputer sebagai tempat belajar dan berkreasi peserta didik, serta adanya jaringan internet khusus untuk akses peserta didik mencari informasi digital mengenai pembelajaran disekolah. Selain itu Madrasah tersebut senantiasa melakukan upaya dalam pengembangan layanan Pendidikan dan Pengajaran yang relevan dengan perkembangan TIK pada saat ini. Hasilnya, MTsN 3 Pasaman menjadi madrasah yang termasuk salah satu Madrasah yang menawarkan keterampilan keahlian bagi para peserta didik dalam bidang TIK (SK Dirjen Pendis No. 2851, 2020).

Dari hasil observasi peneliti diatas, penting sekali Madrasah mengimbangi tuntutan dari perubahan zaman saat ini, terutama di masa Pandemi Covid-19. Madrasah harus mampu bersaing di Era Revolusi Industri 4.0 yang menuntut Madrasah untuk selalu dinamis dan lebih bermanfaat. Walaupun fakta yang ditemukan di lapangan masih banyak Madrasah yang berfokus pada budaya lamanya, kemudian sulitnya beradaptasi dengan perkembangan zaman. Hal ini diduga karena Madrasah tersebut kesulitan dalam mengelola proses pembelajaran, terutama mengelola pembelajaran dengan memadukan dan mencampurkan pembelajaran daring dan luring (Blended Learning). Terlepas dari permasalahan tersebut, MTsN 3 Pasaman dirasa mampu 
dalam menerapkan proses pembelajaran campuran dengan memanfaatkan teknologi dan informasi pembelajaran yang ada pada masa Pandemi Covid-19. Dari pembahasa diatas maka masalah ini penting untuk diteliti, sehingga peneliti memilih fokus penelitian pada manajemen pembelajaran berbasis Blended Learning pada masa Pandemi Covid-19.

\section{Metode}

Penelitian ini menggunakaan pendekatan kualitatif dengan menggunakan metode studi kasus. Penelitian kualitatif mengunakan metode pengumpulan data dengan teknik wawancara, observasi dan dokumentasi (Mohajan, 2018). Penelitian ini dilaksanakan di MTsN 3 Pasaman pada tanggal 20 April 2021. Sumber data utama dalam penelitian ini dikelompokan menjadi dua bagian yaitu, sumber data primer dan sumber data sekunder. Sumber data primer adalah pernyataan dan tindakan orang yang diamati atau diwawancara kemudian direkam melalui catatan tertulis dan pengambilan foto. Sedangkan data sekunder adalah data yang berupa dokumen, foto atau catatan penting lain yang berisikan informasi dari informan.(Apriani et al., 2021)

Penelitian ini dilaksanakan dalam dua tahap, yaitu tahap I dan tahap II. Sebelum dilaksanakan tindakan tahap I tersebut, peneliti melaksanakan tes pra siklus untuk mengetahui pemahaman siswa terhadap materi pokok Indonesia Merdeka dengan tes tertulis pilihan ganda. tahap I digunakan sebagai refleksi untuk melakukan penelitian di tahap II, sedangkan tahap II bertujuan untuk mengetahui peningkatan hasil belajar siswa setelah dilakukan perbaikan pada proses pelaksanaan proses belajar mengajar yang didasarkan pada refleksi siklus I. Secara garis besar terdapat empat tahapan yang lazim dilalui dalam penelitian tindakan kelas dalam setiap tahap, yaitu perencanaan, pelaksanaan tindakan, pengamatan/observasi, dan refleksi.

Teknik tes digunakan untuk mengetahui pemahaman terhadap materi pelajaran dengan menggunakan metode manajemen pembelajaran berbasis blended learning. Tes digunakan untuk mengetahui tingkat pemahaman peserta didik terhadap materi pelajaran sehingga dapat dihasilkan data yang dapat mendukung proses penelitian. Instrumen tes yang diberikan berupa perintah kepada peserta didik untuk mengerjakan tes tertulis pilihan ganda yang disediakan oleh penulis. Adapun yang menjadi fokus sumber data primer dalam penelitian ini adalah 10 orang guru kelas 9 dan 30 siswa MTsN 3 Pasaman, untuk sumber data skunder dalam penelitian ini berupa pengumpulan arsip dan pengambilan dokumentasi. Untuk menjawab permasalah dalam penelitian ini diperlukan teknik dan pengumpulan data yang tepat sehingga penelitian ini dapat menjabarkan data real secara terperinci.(Magdalena \& Nadya, 2020)

\section{Hasil dan Pembahasan}

\section{Pengertian Manajemen Pembelajaran Berbasis Blended Learning}

Menurut Usman (2009:5) istilah manajemen berasal dari bahasa latin yaitu kata manus yang artinya tangan dan agere yang berarti melakukan. Penggabungan dua kata tersebut menjadi bentuk kata kerja manager yang artinya menangani managere diterjemahkan dalam bahasa Inggris menjadi bentuk kata kerja yaitu to manage dengan kata benda adalah management dan manajer adalah orang yang melakukan aktifitas atau kegiatan manajemen. Akhirnya management diterjemahkan dalam bahasa Indonesia menjadi manajemen atau pengelolaan.(Rezeki et al., 2018) Pengertian manajemen menurut para pakar manajemen diantaranya: Harold Koonts dan Cyril O'Donel, manajemen adalah suatu usaha untuk mencapai tujuan tertentu melalui kegiatan orang lain. Dengan demikian Manajer melakukan koordinasi atas sejumlah aktifitas orang lain yang meliputi perencanaan, pengorganisasian, penempatan, pengarahan, dan pengendalian. Sedangkan menurut Malayu S.P. Hasibuan, Manajemen adalah suatu ilmu dan seni yang mengatur proses pemanfaatan sumber daya manusia dan sumber-sumber lainnya secara efektif dan efisien yang berguna untuk mencapai suatu tujuan tertentu. Pernyataan tersebut sejalan dengan pernyataan menurut Prayudi bahwa manajemen adalah suatu pengendalian dan pemanfaatan dari semua faktor dan sumber daya berdasarkan perencanaan (planning) yang diperlukan untuk menyelesaikan dan mencapai suatu tujuan kerja tertentu. Berdasarkan pembahasan diatas maka manajemen adalah suatu proses yang dilakukan oleh seseorang agar suatu usaha dapat berjalan denga baik sesuai dengan yang diharapkan berdasarkan perencanaan, pengaraha, pemikiran, dan pengaturan serta mempergunakan dan mengikutsertaan semua potensi yang ada baik potensi personal maupun material secara efektif dan efesien.(Abdul Halik, 2018)

Pembelajaran pada dasarnya adalah suatu proses, proses yang bertujuan mengatur, mengorganisasi lingkungan yang ada di lingkungan sekitar peserta didik sehingga dapat menumbuhkan dan mendorong minat dan bakat peserta didik dalam melaksanakan proses belajar. Pembelajaran juga diartikan sebagai proses yang memberikan bimbingan atau bantuan kepada para peserta didik dalam melakukan proses belajar. Menurut Trianto, pembelajaran adalah aspek kegiatan yang kompleks dan tidak dapat dijelaskan sepenuhnya. Secara 
sederhana, pembelajaran dapat diartikan sebagai produk interaksi berkelanjtan antara pengembangan dan pengalaman hidup. Pada hakikatnya, Trianto menjelaskan bahwa pembelajaran adalah suatu usaha sadar dari seorang guru untuk memberikan pelajaran kepada peserta didiknya dengan maksud agar tujuan dari belajar tersebut dapat tercapai. Dengan demikian, pembelajaran pada dasarnya adalah kegiatan yang terencana dalam mengkondisikan atau merangsang seseorang agar dapat belajar dengan baik, berdasarkan pada dua kegiatan pokok, yaitu bagaimana seseorang melakukan tindakan perubahan tingkah laku melalui kegiatan belajar dan bagaimana seseorang melakukan tindakan penyampaian dan pemberian ilmu pengetahuan melalui kegiatan mengajar.(A. Pane, 2017)

Manajemen pembelajaran dapat diartikan sebagai suatu proses perencanaan, pelaksanaan dan evaluasi pembelajaran dalam proses pelaksanaan pembelajaran. Menurut pendapat Conners dalam Hasibuan dan Moedjiono (2002:39-40) bahwa fungsi dari manajemen pembelajaran mencakup: (1) perencanaan dalam pembelajaran, (2) pelaksanaan dalam pembelajaran, dan (3) evaluasi dalam pembelajaran.(D. N. Pane et al., 2018)

Secara etimologi istilah blended learning terdiri dari dua kata yaitu blended dan learning. Blend berarti "campuran atau gabungan, bersama untuk meningkatkan kualitas agar bertambah baik", atau formula suatu penyelarasan kombinasi atau penyelarasan perpaduan. Sedangkan learning memiliki makna umum yakni belajar, dengan demikian sepintas mengandung makna pembelajaran yang mengandung arti pencampuran, atau penggabungan yakni antara satu pola dengan pola yang lainnya. Jadi, blended learning adalah kombinasi pembelajaran tradisional dan lingkungan pembelajaran elektronik. Penerapan blended learning diharapkan siswa dapat memahami materi dengan lebih baik dan lebih aktif dalam mengikuti pembelajaran, sehingga dapat meningkatkan hasil belajar siswa.(Rahmati et al., 2020)

Sebagai seorang manajer yang baik, kepala sekolah dan guru harus aktif dalam mencari solusi agar proses pembelajaran disekolah tetap berjalan. Kegiatan dalam merencanakan, melaksanakan dan mengevaluasi proses pembelajaran adalah barometer manajemen pembelajaran. Jika dikaitkan dengan pemanfaatan model pembelajaran Blended Learning yang mengintegrasikan antara luring dengan daring, perencanaan, pelaksanaan dan evaluasi pembelajaran memliliki beberapa perbedaan. Dengan adanya aturan mengenai proses pembelajaran daring maka terjadi perubahan yang menyeluruh pada format RPP, dan format penilaian. Ini membuktikan bahwa guru atau yang berhubungan dengan proses pembelajaran dituntut agar mempunyai kompetensi yang baik di masa pandemi COVID-19 ini.

\section{Pembahasan Hasil Penelitian Tahap I}

Pembahasan hasil penelitian Tahap I meliputi (a) analisis, (b) sintesis, dan (c) evaluasi. Pembahasan hasil penelitian pada siklus I peneliti sajikan sebagai berikut:

\section{Analisis}

Dari hasil data yang didapat oleh observasi, maka proses belajar mengajar yang telah dilakukan dianalisis: proses pembelajaran yang dilakukan masih kurang lancar dan kurang menyenangkan sehingga siswa kurang antusias, kurang bersemangat dalam menerima pelajaran, serta guru tidak menggunakan pendekatan, strategi, metode atau media pembelajaran yang variatif.

\section{Sintesis}

Pada siklus ini dari proses pembelajaran yang telah dilakukan mulai dari perencanaan sampai pada akhir kegiatan, ternyata belum dapat meningkatkan pemahaman siswa sesuai dengan apa yang diharapkan oleh guru. Hal ini disebabkan karena masih adanya kelemahan yang ditemui sehingga masih menjadi rintangan dalam mencapai peningkatan hasil belajar siswa sehingga perlu dilakukan praktek pembelajaran pada tahap II selanjutnya.

\section{Evaluasi}

Berdasarkan hasil data pada proses pembelajaran pada tahap I ini, memperlihatkan bahwa proses pembelajaran memperlihatkan tingkat keberhasilan belajar siswa secara klasikal masih di bawah standar (tidak tuntas) yaitu 15 orang siswa dari jumlah total 30 orang siswa dan baru 15 orang siswa lainnya dinyatakan tuntas belajar. Nilai rata-rata kelas 74,51 (masih dibawah KKM) meskipun hampir mendekati KKM 75, dan ketuntasan belajar berada pada angka 58,30\% masih di bawah standar yang telah disepakati, maka untuk itu perlu dilakukan kembali penelitian hasil Tahap II.

\section{Pembahasan Hasil Penelitian Tahap II}

Pembahasan hasil penelitian siklus II meliputi (a)analisis, (b) sintesis, dan (c) evaluasi. Pembahasanhasil penelitian pada siklus II peneliti sajikan sebagai berikut: 


\section{Analisis}

Setelah diadakan proses pembelajaran tahap II menggunakan model blended learning yang diikuti oleh seluruh siswa pada kelas yang sama dan dilakukan sesuai dengan perencanaan dan skenario pembelajaran, maka proses pembelajaran berjalan dengan baik, lancar dan kondusif.

\section{Sintesis}

Setelah diadakan tahap II yang diikuti oleh seluruh siswa pada kelas yang sama dan dilakukan sesuai dengan perencanaan dan skenario pembelajaran, maka proses pembelajaran berjalan dengan baik, lancar dan kondusif.

\section{Evaluasi}

Hasil evaluasi proses perbaikan pembelajaran menggunakan manajemen pembelajaran pada masa pandemi covid-19 berbasis blended learning di kelas XI MTsN 3 Pasaman dengan penerapan system proses pembelajaran campur antara online dan offline untuk meningkatkan hasil belajar siswa kelas XI MTsN 3 Pasaman pada 10 mata pelajaran berbeda ,membuktikan bahwa perubahan peningkatan hasil belajar siswa memperoleh nilai rata - rata kelas 74,51 pada kondisi awal (pra siklus) masih rendah, berubah nilai rata - rata kelas meningkat secara signifikan menjadi 84,44 sebesar $78.13 \%$ pada siklus II.

\section{Model Manajemen Pembelajaran Pada Masa Pandemi Covid-19 Berbasis Blended Learning di MTsN 3 Pasaman}

Manajemen Pembelajaran pada masa pandemi Covid-19 Berbasis Blended Learning di MTsN 3 Pasaman dapat dilihat melalui uraian kurikulum yang digunakan pada masa Pandemi Covid-19, Rencana Pelaksanaan Pembelajaran (RPP) yang disusun oleh masing-masing guru, beserta kesiapan sarana dan prasarana sekolah yang disesuaikan dengan kebutuhan pada saat ini. Fokus utama perencanaan pembelajaran adalah Kurikulum. Terdapat tiga landasan yang menjadi acuan dalam mengembangkan kurikulum, yaitu landasan filosofis, landasan psikologis, dan landasan sosiologis-teknologis. Pada landasan filosofis, tujuan pendidikan yang disusun dalam kurikulum harus mengandung tiga hal, yaitu autonomy (menciptakan kemandirian), equity (kesempatan yang sama), dan survival (mempertahakan budaya yang ada). Dalam landasan psikologi, pengembangan kurikulum harus mempertimbangkan psikologi perkembangan peserta didik. Sedangkan landasan sosiolgis-teknologis menjadi acuan dalam melakukan pengembangan kurikulum untuk melihat kondisi dari lingkungan dan perkembangan teknologi dari masa ke masa.(Rahmati et al., 2020)

Dalam hal ini keadaan psikologis peserta didik harus tetap di bina sebaik mungkin agar kestabilan emosional dapat di kontrol dengan baik. Kurikulum Darurat yang dikembangkan di MTsN 3 Pasaman disesuaikan dengan model pembelajaran Blended Learning yaitu model yang menggunakan sistim kolaborasi lintas matpel. Pada landasan filosofis dan psikologis, struktur kurikulum dan muatan mata pelajaran yang ada di MTsN 3 Pasaman disesuaikan dengan visi dan misi madrasah serta kondisi peserta didik. Selain itu, metode pembelajaran berbasis Blended Learning yang diterapkan di MTsN 3 Pasaman juga dapat menumbuhkan sifat mandiri dan tanggung jawab peserta didik. Beberapa penelitian yang di lakukan diantaranya dari (Wardani et al., 2018) menjelaskan bahwa Blended learning adalah kegiatan pembelajaran yang dapat dilakukan di kelas maupun diluar kelas dengan memanfaatkan berbagai teknologi untuk menambah materi pelajaran dan soalsoal yang diberikan di kelas maupun melalui online yang dikelola dan dikontrol sedemikan rupa oleh guru agar kegiatan pembelajaran dapat berlangsung dengan baik, serta komunikasi antar siswa dan guru dapat terjalin baik pada saat berada di kelas maupun di luar kelas (online) dengan membentuk sebuah grup diskusi yang memanfaatkan teknologi yang tersedia di era ini karena pembelajaran tanpa adanya komunikasi hasilnya tidak akan sesuai dengan harapan baik dari guru mapun peserta didik. Model pembelajaran blended merupakan suatu model pembelajaran yang menggabungkan metode pengajaran secara face to face dengan metode pengajaran berbasis komputer baik dilakukan secara offline maupun online yang berguna untuk membentuk suatu pendekatan pembelajaran yang terintegrasi.

Model Blended ini adalah inovasi yang bertujuan membentuk kreatifitas siswa dan guru. Siswa dituntut untuk menyelesaikan tugas yang di berikan guru baik melalui hard copy maupun melalui soft copy/tehnologi informasi. Sesuai dengan perkembangan sosial nya siswa pada jenjang MTsN ini sangat mengandrungi penggunaaan teknologi pada saat ini seperti komputer, laptop, maupun HP sehingga minat dan daya belajar mereka bisa mengalami peningkatan. Hal ini di buktikan oleh penelitian kualitatif deskriptif Yunika Lestaria Ningsih (2017 terkait manfaat pembelajaran dengan metode blanded learning sebagai berikut: (1) peningkatan hasil belajar Metode Statistika mahasiswa yang mendapat pembelajaran Blended Learning lebih baik daripada mahasiswa yang mendapat pembelajaran biasa, baik ditinjau secara keseluruhan maupun berdasarkan level KAM, (2) peningkatan kemandirian belajar mahasiswa yang mendapat pembelajaran Blended Learning lebih baik daripada mahasiswa yang mendapat pembelajaran biasa, untuk keseluruhan mahasiswa, level KAM tinggi dan sedang. Sedangkan pada KAM rendah, peningkatan kemandirian belajar mahasiswa yang 
mendapat pembelajaran Blended Learning tidak lebih baik daripada mahasiswa yang mendapat pembelajaran biasa.(Ningsih et al., 2017) Berdasarkan pembahasan tersebut dosen atau tenaga pengajar disarankan menerapkan model Blended Learning dalam upaya meningkatkan hasil belajar matematika mahasiswa.

\section{Metode Pembelajaran Model Blended Learning.}

Dalam penerapan pembelajaran berbasis Blended Learning tentu ada beberapa metode yang di gunakan mengingat hal ini akan diterapkan menjadi kebiasaan baru dalam sistim pembelajaran. Selain metode-metode yang sudah sering di pakai maka salah satu metode yang sudah di uji ke efektifitas nya adalah metode Flipped Classroom. Flipped Classroom adalah suatu strategi pembelajaran campuran yang membalikkan model pengajaran dan pembelajaran dalam dunia Pendidikan secara tradisional. Ketika pembelajaran dengan strategi Flipped Classroom, pembelajaran didaktik yang biasanya berlangsung selama waktu tatap muka, sebelumnya direkam dan disediakan bagi peserta didik untuk menonton sebelum kelas tatap muka, sementara kesempatan untuk memperdalam, memperluas dan menerapkan pemahaman peserta didik tentang materi yang direkam adalah dengan cara strategi pembelajaran aktif di waktu pembelajaran di kelas.(Usmadi \& Ergusni, 2019) Flipped Classroom ini hakikatnya merupakan sebuah metode dalam penerapan blended learning itu sendiri. Dengan pendekatan Flipped Classroom, sebagian aktivitas yang dilakukan dalam pembelajaran yang biasanya diselesaikan di kelas, kini dapat diselesaikan di rumah dan dilakukan secara mandiri oleh siswa sebelum akhirnya melakukan proses pembelajaran tatap muka lagi di kelas. Dalam menerapkan model pembelajaran ini pada konteks pembatasan pembelajaran tatap muka di semester baru, terdapat 6 langkah umum yang bisa diterapkan dalam rangka memastikan pembelajaran tetap efektif

\section{Langkah-langkah penerapan Flipped Classroom sebagai berikut:}

Membagi siswa dalam kelas menjadi 2 kelompok besar. Kelompok 1 akan melakukan pembelajaran tatap muka pada periode minggu pertama dan pembelajaran daring di periode minggu selanjutnya, sementara Kelompok 2 akan melakukan proses pembelajaran daring di periode minggu pertama dan pembelajaran tatap muka di periode selanjutnya. Membagi materi pelajaran menjadi 2 kategori. Kategori A adalah materi yang akan dipelajari oleh siswa secara mandiri dan Kategori B yang perlu dipandu/didiskusikan bersama guru dan teman sebaya. Untuk siswa kelompok 1, periode minggu pertama digunakan untuk pembelajaran tatap muka dimana pembelajaran tersebut berfokus pada materi Kategori B yang lebih menekankan pada diskusi dan aktivitas proses pembelajaran yang dipandu langsung oleh guru. Setelah itu, pada periode selanjutnya saat siswa melakukan proses belajar di rumah, maka guru dapat melakukan pembelajaran secara daring yang menekankan pada materi ajar yang ada pada kategori A. Untuk siswa Kelompok 2, periode minggu pertama digunakan untuk melaksanakan proses pembelajaran daring yang berfokus pada materi kategori A yang lebih menekankan kepada aktivitas penugasan mandiri yang dapat dilakukan siswa dari rumah. Setelah itu, pada periode minggu selanjutnya saat siswa belajar ditatap muka disekolah, guru dapat berfokus menjelaskan materi kategori B dengan mengadakan aktivitas diskusi disertai dengan pembelajaran aktif lainnya saat di kelas. Pastikan dalam pelaksanaannya guru dapat mengatur waktu dengan baik agar jam pembelajaran siswa Kelompok 1 dan Kelompok 2 tidak saling bertabrakan. Contohnya, pembelajaran tatap muka bisa dilakukan pada pagi hari dan pembelajaran daring mandiri bisa dilakukan di siang hari. Lakukan review dan refleksi secara rutin dan berkala untuk mengecek pemahaman siswa serta umpan balik mengenai kendala ataupun kesulitan yang dihadapi oleh siswa selama mereka mengikuti proses pembelajaran blended learning ini.

Dalam penerapan metode tersebut terdapat dua situasi yang di alami siswa. yaitu tugas mandiri di kerjakan dirumah dan di diskusikan di sekolah. Begitu juga guru yang tidak sepenuhnya dapat mendampingi siswa dikarenakan keterbatasan waktu. Namun karena saat ini belajar memiliki kebiasaan baru maka disinilah dituntut kreativitas seorang guru dalam merancang pembelajaran sehingga dapat menyenangkan dan tujuan pembelajaran yang di harapkan dapat tercapai dengan baik

.Jadwal pembelajaran tatap muka di MTsN 3 Pasaman berlaku secara normal yaitu masuk dari hari Senin hingga Sabtu. Setiap hari siswa mengikuti proses pembelajaran secara tatap muka disekolah. Pesentasi daring pembelajaran berkisar antara 30-35 \% (sumber wawancara Kepala Sekolah) Untuk jadwal pembelajaran daring akan disesuaikan dengan kebutuhan guru pada masing-masing mata pelajaran yang diampu. Jadwal pembelajaran tatap muka ini dilakukan dengan menggunakan model shift, yaitu satu minggu belajar secara luring dengan jumlah siswa max 25 orang, dan pada minggu lainnya melalui daring di rumah. Jika dibandingkan dengan waktu belajar dalam perspektif model Blended Learning didapatkan persentase pembelajaran daringnya rendah berkisar 30-35\%, namun pada ujian atau evaluasi pembelajaran harus dilakukan secara daring. Sementara itu, pelaksanaan evaluasi bisa dilakukan secara daring maupun luring dengan pesentase 80-90 \%. Komposisi Blended Learning disesuaikan dengan kebutuhan pembelajaran. Komposisi yang sering digunakan adalah 60\% untuk kegiatan tatap muka/luring, 40\% digunakan untuk kegiatan online/daring. Namun metode Blended Learning yang diterapkan di MTsN 3 Pasaman 
menggunakan $75 \%$ pembelajaran tatap muka/luring dan $25 \%$ pembelajaran online/daring. Dalam proses penerapan metode ini juga tidak terlepas dari perencanaan pembelajaran.

Perencanaan pembelajaran yang pertama adalah Rencana Pelaksanaan Pembelajaran (RPP). Kewajiban seorang guru dalam melaksanakan proses pembelajaran ada tiga, yaitu membuat perencanaan pembelajaran, kemudian melaksanakan kegiatan pembelajaran dan melakukan evaluasi proses pembelajaran (Hidayah et al., 2016). Abdul Majid dalam bukunya, Perencanaan Pembelajaran menyebutkan, bahwa perencanaan berarti menyusun langkah-langkah penyelesaian suatu masalah atau melaksanakan suatu pekerjaan secara terarah untuk mencapai tujuan tertentu. Perencanaan mencakup rangkaian kegiatan yang dilakukan untuk menentukan tujuan umum(goal) dan tujuan khusus (objektivitas) suatu organisasi atau lembaga penyelenggara pendidikan, berdasarkan dukungan informasi yang lengkap. Sedangkan Abdul Latif menyebutkan bahwa pengajaran adalah suatu pemikiran tentang berbagai penerapan prinsip-prinsip umum mengajar pada pelaksanaan tugas mengajar dalam suatu situasi interaksi pengajaran (interaksi antara guru dan siswa) tertentu yang khusus,baik yang berlangsung didalam kelas maupun diluar kelas. Jika dua pengertian perencanaan dan pengajaran tersebut digabungkan, maka perencanaan pengajaran adalah suatu persiapan yang harus dipersiapkan oleh setiap pendidik sebelum mengadakan proses interaksi belajar mengajar dengan peserta didik di dalam kelas maupun di luar kelas.(Qasim \& Maskiah, 2016)

Dengan kata lain, penjelasan dari seluruh kegiatan dan aktivitas pembelajaran di kelas sangat tergantung pada Rencana Pelaksanaan Pembelajaran (RPP). Sedangkan hakikat dari RPP adalah suatu upaya yang berfungsi untuk memperkirakan tindakan apa yang akan dilakukan oleh guru dalam melaksanakan kegiatan pembelajaran (Mulyasa, 2008). Penyusunan RPP yang baik dimulai dengan penentuan tujuan pembelajaran yang tepat (Sagala, 2009). Sebagaimana telah disebutkan di atas bahwa tujuan pembelajaran merupakan komponen utama dalam RPP karena yang menjadi titik acuan dari seluruh aktivitas pembelajaran yang disusun dalam RPP adalah tujuan pembelajaran. Oleh sebab itu, RPP baik tatap muka/luring maupun online/daring yang di susun oleh guru dan Tim MGMP matpel di MTsN 3 Pasaman memuat tujuan pembelajaran yang sesuai dengan modul atau buku mata pelajaran. Dari tujuan pembelajaran tersebut maka dirumuskan Kompetensi Inti (KI) dan Kompetensi Dasar (KD), serta indikator sebagai target ketercapaian melalui kegiatan pembelajar disekolah.

Perencanaan pembelajaran yang kedua adalah sarana dan prasaran di sekolah. Sarana adalah segala sesuatu yang dapat digunakan sebagai alat penunjang dalam mencapai maksud atau tujuan dari pendidikan. Menurut E. Mulyasa, Sarana Pendidikan adalah peralatan dan perlengkapan yang secara langsung dipergunakan untuk menunjang proses pendidikan, khususnya proses belajar, mengajar, meliputi bangunan, ruang kelas, meja kursi, serta alat-alat dan media pengajaran. Sarana pendidikan merupakan sarana penunjang bagi proses belajar-mengajar. Menurut Ibrahim Bafadal yang dimaksud prasarana pendidikan adalah semua perangkat kelengkapan dasar yang secara tidak langsung berguna untuk menunjang pelaksanaan proses pendidikan di sekolah. Secara etimologis (bahasa) sarana pendidikan berarti alat langsung untuk mencapai suatu tujuan pendidikan. meliputi; ruang, buku, perpustakaan, laboratorium dsb. Dengan penjelasan tersebut dapat ditarik kesimpulan bahwa sarana dan prasarana pendidikan adalah semua komponen yang secara langsung maupun tidak langsung menunjang jalannya proses pendidikan guna mencapai tujuan dalam pendidikan itu sendiri. Sedangkan prasaran pendidikan adalah alat tidak langsung untuk mencapai tujuan dalam pendidikan. misalnya: lokasi/tempat, bangunan sekolah, lapangan olahraga, uang dan lainnya.(Mulyana, 2005)

Implementasi model pembelajaran berbasis Blended Learning yang baik tidak terlepas dari sejumlah permasalahan di atas. Oleh sebab itu, ketersediaan sarana prasarana pembelajaran di sekolah menjadi faktor pendukung utama dalam proses pembelajaran berbasis Blended Learning. Beberapa sarana prasarana yang diperlukan sekolah berupa ruang kelas di sekolah atau,akses internet dan aplikasi pembelajaran daring, serta sarana lain yang menjadi pendukung efektivitas pembelajaran. Hasil penelitian menunjukkan bahwa MTsN 3 Pasaman dalam perencanaan pembelajaran berbasis Blended Learning pada masa Pandemi Covid-19 telah melakukan persiapan sarana prasarana pembelajaran berupa ruang kelas, akses internet, aplikasi pembelajaran, serta laboratorium komputer sebagai sarana alternatif dalam pelaksanaan pembelajaran daring apabila proses pembelajaran dilakukan disekolah. Pengelolaan ruang kelas di masa pandemi Covid-19 di MTsN 3 Pasaman menerapkan sistem belajar shift dengan jumlah siswa yang dibatasi 50\% tiap kelas, maka satu bangku untuk satu siswa. Pada masa normal satu bangku ditempati oleh dua siswa.

Dalam pengaturan ruang kelas, hal-hal yang menjadi perhatian demi kelancaran proses pembelajaran adalah ukuran dan bentuk kelas, meja atau bangku peserta didik, jumlah peserta didik dalam kelas, beserta komposisi peserta didik berdasarkan kepandaian dan jenis kelamin (Badrudin, 2014). Keputusan MTsN 3 Pasaman dalam menentukan jumlah siswa per kelas sebesar 50\%. Hal ini diterapkan karena regulasi 
Pendidikan saat ini mengharuskan jumlah siswa terbatas dalam kegiatan pembelajaran luring atau tatap muka pada masa Pandemi Covid-. Pembelajaran online dengan e-learning tidak akan terlepas dari internet, karena seluruh interaksi pada proses pembelajaran di e-learning selalu membutuhkan jaringan internet yang memadai. Jaringan internet yang tersedia disekolah akan sangat berpengaruh pada tugas guru dalam proses pembelajaran disekolah (Miarso, 2004). Oleh sebab itu, MTsN 3 Pasaman juga menyediakan akses internet di sekolah. Fasilitas ini bisa digunakan tidak hanya oleh guru, tapi juga oleh siswa yang dalam proses pembelajaran. Sedangkan untuk jaringan internet siswa untuk belajar secara mandiri di rumah, MTsN 3 Pasaman tidak menyediakan bantun khusus kuota internet dari sekolah.

Selain aplikasi dalam pembelajaran daring dan akses internet, sarana lain yang berkaitan dengan pembelajaran berbasis Blended Learning adalah perangkat Teknologi Informasi dan Komunikasi (TIK). Komponen TIK berkaitan dengan perangkat komunikasi dan informasi seperti komputer, software, handphone, satelit komunikasi, sarana wifi, aplikasi konferensi virtual, media sosial elektronik, dan lain-lain (Roy, 2015). Proses pembelajaran daring sangat membutuhkan perangkat komputer, baik dalam bentuk CPU ataupun laptop. Komputer dan teknologi yang serupa telah digunakan di dunia pendidikan dalam berbagai bentuk dan tujuan, contohnya pertama untuk mengajar, tugas menulis, dan lain-lain; kedua, untuk melaksanakan program simulasi belajar mandiri demi meningkatkan kemampuan berpikir kognitif peserta didik; ketiga, untuk melakukan komunikasi melalui internet dan media komunikasi lainnya; dan keempat sebagai alat kerja yang produktif, seperti untuk database dan lain-lain (Dabas, 2018). Sarana komputer dan teknologi informasi di MTsN 3 Pasaman sudah termasuk lengkap, sekolah tersebut memiliki ruang laboratorium komputer khusus yang bisa digunakan oleh siswa untuk melaksanakan pembelajaran daring di sekolah.

Implementasi pembelajaran berbasis Blanded Learning yang ketiga adalah pengelolaan waktu pembelajaran. Dalam menyusun RPP, salah satu komponen yang dicantumkan adalah alokasi waktu belajar. Artinya, seorang guru harus merencanakan dengan tepat pembagian waktu seluruh kegiatan belajar di kelas agar proses pembelajaran bisa berjalan secara efektif, dan hasil yang diperoleh pun bisa maksimal. Seorang guru dalam menentukan alokasi waktu belajar harus didasarkan pada estimasi kemampuan yang bisa dicapai oleh siswa dalam waktu yang tersedia (Badrudin, 2014). Pada masa Pandemi Covid-19, waktu belajar tatap muka yang disediakan hanya 30 menit per jam pelajaran. Tentu saja hal ini akan menjadi tantangan tersendiri bagi guru dalam mengelola waktu belajar di kelas agar proses pembelajaran tetap berjalan dengan efektif. Dengan waktu yang sangat terbatas tersebut, guru di MTsN 3 Pasaman memaksimalkan pengaturan dan pengelolaan waktu belajar. Hal ini dibuktikan dari beberapa orang guru yang melewati waktu belajar sesuai dengan jadwal yang telah dijadwalkan.

Meskipun model pembelajaran menjadi salah satu solusi dalam penyampaian materi dalam proses pembelajaran pada masa Pandemi Covid-19, kebanyakan dari peserta didik masih lebih menyukai pembelajaran tatap muka/luring. Berdasarkan hasil penelitian yang didapat sebanyak (45.2\%), siswa menyukai pembelajaran tatap muka sedangkan sisanya menyukai model pembelajaran online/daring (10.8\%) dan model Blended Learning (35\%) (Mustakim, 2020).

Hasil penelitian di MTsN 3 Pasaman menunjukkan bahwa laporan hasil belajar di madrasah dilakukan dengan memanfaatkan aplikasi berupa website yang digunakan untuk melakukan evaluasi pembelajaran online/daring pada beberapa matpel yang dianggap mampu dalam penerapannya. . Pada software tersebut, hasil belajar siswa secara otomatis akan diolah dan bisa dilihat hasilnya secara langsung (real time online). Para guru tidak perlu susah payah mengoreksi hasil evaluasi siswa secara manual. Sedangkan nilai akhir yang dimasukkan ke dalam buku rapor siswa, MTsN 3 Pasaman menggunakan Aplikasi Rapor Digital (ARD). Meskipun aplikasi ini adalah aplikasi online/daring, untuk pengolahannya masih belum terintegrasi langsung dengan nilai di website evaluasi pembelajaran daring satuan pendidikan. Nilai yang ada pada aplikasi evalusi pembelajaran daring harus diolah terlebih dahulu secara manual sebelum dimasukkkan ke Aplikasi Rapor Digital (ARD).

\section{Simpulan}

Manajemen Pembelajaran Pada Masa Pandemi Covid-19 Berbasis Blended Learning di MTsN 3 Pasaman meliputi Manajemen, perencanaan model pembelajaran, , dan evaluasi pembelajaran. Pada tahap perencanaan, MTsN 3 Pasaman menyusun kurikulum khusus yang disesuaikan dengan masa Pandemi Covid19 melalui model pembelajaran berbasis Blended Learning. Model pembelajaran ini menjadi salah satu solusi di tengah permasalahan pendidikan pada masa Pandemi Covid-19 yang sebelumnya menerapkan pembelajaran daring secara penuh. Madrasah menyusun jadwal pembelajaran dengan komposisi yang sama antara pembelajaran tatap muka dan daring, yaitu 60:40. Berdasarkan hasil penelitian dan pembahasan, diperoleh kesimpulan sebagai berikut: 1) Penerapan manajemen pembelajaran pada masa pandemic berbasis 
blended learning di MTsN 3 Pasaman terbukti pada tahap I skor rata-rata hasil aktivitas belajar siswa 74,51 dengan ketuntasan belajar klasikal sebesar 56,26\%, meningkat pada siklus II yaitu skor rata-rata sebesar 84,44 dengan persentasi ketuntasan belajar (KKM) sebesar 75) Penerapan manajemen pembelajaran pada masa pandemic berbasis blended learning di MTsN 3 Pasaman terbukti pada tahap I skor rata-rata hasil belajar siswa 74,51 dengan 15 orang siswa belum tuntas dan 15 orang siswa tuntas dari jumlah total 30 orang siswa, meningkat pada siklus II yaitu 84,44 dengan 27 orang siswa yang tuntas dan 3 orang siswa belum tuntas pada proses pembelajaran tersebut.

\section{References}

Abdul Halik. (2018). Peran manajemen pembelajaran akidah akhlak dalam pembentukan akhlakul karimah. Istiqra, 5 (2 ,Maret).

Apriani, Y., Asrin, Fahrudin, \& Muhaimi, L. (2021). Manajemen Pembelajaran Daring pada Masa Pandemi Covid-19 Di SD IT Lombok Tengah. Jurnal Ilmiah Mandala Education, 7(2), 271-277.

Islamic, J., \& Manajemen, E. (2020). p-ISSN: 2541-383X e-ISSN: 2541-7088. 5(2), 201-220.

Kurniawati, I. (2021). Manajemen Pembelajaran Jarak Jauh pada Mata Pelajaran PAI dan BP SMP di Kota Tegal. 9(1), 23-38.

Magdalena, I., \& Nadya, R. (2020). Pengelolaan Pembelajaran Di Masa Pendemi Covid 19 Dengan Blended Learning. Jurnal Edukasi Dan Sains, 2(3), 401-409.

Mulyana, E. (2005). Manajemen Sarana Prasarana. Manajemen Sarana Prasarana Pendidikan, 8(1), 8. https://journal.uinsgd.ac.id/index.php/isema/article/view/5645

Ningsih, Y. L., Misdalina, M., \& Marhamah, M. (2017). Peningkatan Hasil Belajar dan Kemandirian Belajar Metode Statistika Melalui Pembelajaran Blended Learning. Al-Jabar: Jurnal Pendidikan Matematika, 8(2), 155. https://doi.org/10.24042/ajpm.v8i2.1633

Pane, A. (2017). Belajar dan Pembelajaran Aprida Pane Muhammad Darwis Dasopang. Fitrah, 03(2), 333352.

Pane, D. N., Fikri, M. EL, \& Ritonga, H. M. (2018). MANAJEMEN PEMBELAJARAN PONDOK PESANTREN (Studi Kasus Pondok Pesantren Darussalam Kemiri Barat Subah Batang) Oleh. Journal of Chemical Information and Modeling, 53(9), 1689-1699.

Qasim, M., \& Maskiah. (2016). Perencanaan Pengajaran dalam Kegiatan Pembelajaan. Jurnal Diskursus Islam, 4(3), 484-492.

Rahmati, Nuraini, \& Nazariati. (2020). Manajemen Pembelajaran Berbasis Blended Learning Pada Masa Pandemi Covid-19 (Studi Kasus Di Sman 1 Dewantara Aceh Utara). 19, 114-135.

Rezeki, S., AR, M., \& Harun, C. Z. (2018). Amandemen Pembelajaran Pendidikan dan Pelatihan Prajabatan pada BKPP Aceh. Jurnal Pendidikan Serambi Ilmu, 13(No. 2), 81-90. http://www.jurnal.unsyiah.ac.id/JAP/article/view/2586

Usmadi, U., \& Ergusni, E. (2019). Penerapan Strategi Flipped Classroom dengan Pendekatan Scientific dalam Pembelajaran Matematika pada Kelas XI SMKN 2 Padang Panjang. Jurnal Eksakta Pendidikan (Jep), 3(2), 192. https://doi.org/10.24036/jep/vol3-iss2/333

Wardani, D. N., Toenlioe, A. J. E., \& Wedi, A. (2018). Daya Tarik Pembelajaran Di Era 21 Dengan Blended Learning. Jurnal Kajian Teknologi Pendidikan (JKTP), 1(1), 13-18. https://core.ac.uk/download/pdf/287323676.pdf 